\title{
PEMURNIAN MINYAK GORENG BEKAS MENGGUNAKAN ADSORBEN BIJI ALPUKAT TERAKTIVASI
}

\author{
Fitriani $^{1}$, Nurulhuda ${ }^{2}$ \\ ${ }^{1,2}$ Prodi Pendidikan Kimia FKIP Universitas Muhammadiyah Pontianak \\ Jalan Ahmad Yani No. 111 Pontianak Kalimantan Barat \\ E-mail: bungafi3ani@gmail.com
}

DOI: $10.26418 /$ jpmipa.v9i2.26770

\begin{abstract}
This research had been conducted in the use of avocado seed powder (Persea americana Mill) as an adsorbent to reduce peroxide and free fatty acids of the used cooking oil. The aim of this research was to determine the best activator of avocado seed powder as an adsorbent to reduce peroxide and free fatty acids of the used cooking oil. This research used the variation of activators, consist of hydrochloric acid ( $\mathrm{HCl})$, citric acid $\left(\mathrm{C}_{6} \mathrm{H}_{8} \mathrm{O}_{7}\right)$, sodium chloride $(\mathrm{NaCl})$ and sodium hydrogen phosphate $\left(\mathrm{Na}_{2} \mathrm{HPO}_{4}\right)$ solutions. The result showed that the best activator of avocado seed powder by $\mathrm{HCl}$ which gave the highest free fatty acid reduction was 0,26\%. Meanwhile, the best activator of avocado seed powder by $\mathrm{C}_{6} \mathrm{H}_{8} \mathrm{O}_{7}$ which gave the highest peroxide value reduction was $1,8 \mathrm{Meq} / \mathrm{Kg}$. These results had qualified as the maximum limits of SNI cooking oil were $0.3 \%$ for the concentration of free fatty acids and $2 \mathrm{Meg} / \mathrm{Kg}$ for the peroxide value of cooking oil.

Keywords: adsorbent, avocado seed powder, used cooking oil
\end{abstract}

Salah satu bahan pangan yang dibutuhkan masyarakat sehari-hari baik di industri maupun rumah tangga adalah minyak goreng. Penggunaan minyak goreng berulang kali dalam proses penggorengan dapat menurunkan mutu dan perubahan sifat fisikokimia (kerusakan minyak). Perubahan tersebut menghasilkan warna minyak goreng menjadi gelap, kental, timbul busa dan berbau, meningkatnya kadar air, bilangan peroksida atau Peroxide Value (PV) dan asam lemak bebas atau Free Fatty Acids (FFA) (Ketaren, 2008). Hal ini dikarenakan pemanasan berulang kali pada suhu tinggi sekitar
160-180 ${ }^{\circ} \mathrm{C}$ yang disertai adanya kontak dengan air dan udara dapat menyebabkan terjadinya reaksi degradasi berupa proses oksidasi, polimerisasi, hidrolisis dan reaksi dengan logam (Kalapathy \& Proctor, 2000). Selain dapat menurunkan mutu bahan pangan yang digoreng, produk reaksi degradasi minyak goreng juga dapat menimbulkan dampak negatif bagi kesehatan (Suirta, 2009). Oleh karena itu, perlu adanya upaya pemurnian minyak goreng bekas sehingga dapat dipakai kembali tanpa mengurangi mutu bahan pangan yang digoreng dan aman dikonsumsi. 
Pemurnian minyak goreng bekas merupakan pemisahan produk reaksi degradasi berupa air, peroksida, asam lemak bebas, aldehid dan keton dari minyak. Salah satu cara yang dapat dilakukan untuk meningkatkan mutu minyak goreng bekas adalah dengan adsorpsi menggunakan adsorben sehingga mutu minyak goreng dapat dipertahankan (Wijayanti, dkk., 2012). Proses adsorpsi menggunakan suatu bahan yang dapat mengadsorpsi kotoran pada minyak yang disebut dengan adsorben. Proses adsorpsi minyak goreng bekas dapat dilakukan dengan penambahan adsorben yang dicampur dengan minyak, dilanjutkan dengan pengadukan dan penyaringan (Ketaren, 2008).

Beberapa peneliti terdahulu telah melakukan penelitian pemurnian minyak goreng bekas menggunakan adsorben dari bahan alami dengan memanfaatkan produk samping atau limbah pertanian, seperti ampas tebu (Ramdja, dkk., 2010), arang aktif dari sabut kelapa (Yustinah dan Hartini, 2011), karbon aktif dari biji kelor (Dahlan, dkk., 2013), ampas pati aren dan bentonit (Rahayu dan Purnavita, 2014) dan arang aktif dari kulit salak (Mangallo, dkk., 2014). Tiap jenis adsorben memiliki selektivitas dalam mengadsorpsi komponen tertentu yang ada dalam minyak goreng bekas. Dalam penelitian ini dilakukan pemanfaatan limbah biji alpukat yang selanjutnya diaplikasikan sebagai adsorben minyak goreng bekas.

Menurut Alsuhendra, dkk (2007), biji alpukat memiliki kandungan air sebesar $12.67 \%$, kadar abu sebesar $2.78 \%$ dan kandungan mineral sebesar $0.54 \%$, lebih tinggi dari biji buah lainnya. Selain itu, kadar pati yang cukup tinggi dari biji alpukat, yaitu sekitar 23\%, serta kadar selulosa yang jumlahnya relatif lebih sedikit daripada pati. Hal ini menyebabkan limbah biji alpukat berpotensi dijadikan sebagai adsorben.

Pada penelitian ini dilakukan pemurnian minyak goreng bekas menggunakan biji alpukat sebagai adsorben teraktivasi untuk menurunkan kadar asam lemak bebas dan bilangan peroksida sebagai parameter tingkat kerusakan minyak. Pemurnian minyak goreng bekas ini diharapkan dapat memperpanjang umur simpan minyak goreng tanpa membahayakan kesehatan konsumen dan memenuhi syarat untuk dapat dikonsumsi kembali.

\section{METODE}

\section{Alat dan Bahan}

Alat-alat yang digunakan dalam penelitian ini antara lain: Labu takar, beaker glass, erlenmeyer, penyaring Buchner, gelas ukur, pipet tetes, pipet volume, corong, neraca digital, pengaduk magnet, buret, termometer, pH-meter, oven, magnetic stirrer, stop watch, saringan halus (100 mesh), hot plate, blender, kertas saring, kertas $\mathrm{pH}$ universal, sentrifuse, corong dan desikator.

Bahan-bahan yang digunakan adalah minyak goreng bekas, serbuk biji alpukat, asam klorida $(\mathrm{HCl})$, asam sitrat $\left(\mathrm{C}_{6} \mathrm{H}_{8} \mathrm{O}_{7}\right)$, natrium klorida $(\mathrm{NaCl})$, natrium hidrogen fosfat $\left(\mathrm{Na}_{2} \mathrm{HPO}_{4}\right)$, kalium hidroksida $(\mathrm{KOH})$, natrium thiosulfat $\left(\mathrm{Na}_{2} \mathrm{~S}_{2} \mathrm{O}_{3}\right)$, kalium iodida (KI), amilum, asam asetat glasial 
$\left(\mathrm{CH}_{3} \mathrm{COOH}\right)$, kalium bromat $\left(\mathrm{KBrO}_{3}\right)$ atau kalim iodat $\left(\mathrm{KIO}_{3}\right)$, asam oksalat $\left(\mathrm{C}_{2} \mathrm{H}_{2} \mathrm{O}_{4}\right)$, indikator phenolptalin, ethanol $96 \%$, chloroform dan aquades.

2. Cara Kerja

a. Preparasi dan Aktivasi
Adsorben
Alpukat

Biji alpukat dikupas, kemudian dipotong-potong dan dicuci dengan air serta dikeringkan dengan cara dijemur di bawah sinar matahari. Selanjutnya biji alpukat dihaluskan sampai berbentuk bubuk dengan ukuran 100 mesh. Adsorben diaktivasi dengan larutan $\mathrm{HCl} 1 \mathrm{M}$ dengan rasio adsorben : asam klorida (b:v) sebesar $1: 2$ selama 2 jam. Kemudian dicuci dengan aquadest untuk menghilangkan residu asam hingga $\mathrm{pH}$ netral. Adsorben dikeringkan di dalam oven pada suhu $60{ }^{\circ} \mathrm{C}$ selama 24 jam dan didinginkan dalam desikator. Prosedur diulangi untuk berbagai variasi aktivator, yaitu, $\mathrm{C}_{6} \mathrm{H}_{8} \mathrm{O}_{7} 1 \mathrm{M}, \mathrm{NaCl} 1 \mathrm{M}$ dan $\mathrm{Na}_{2} \mathrm{HPO}_{4} 1 \mathrm{M}$.

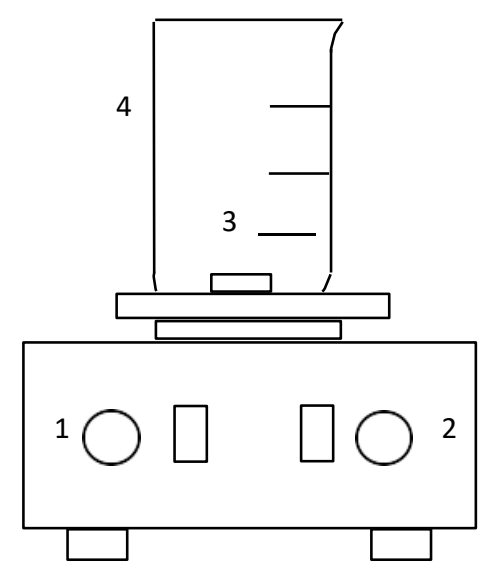

Gambar 1. Rangkaian alat percobaan untuk pemurnian minyak goreng bekas menggunakan adsorben serbuk biji alpukat.

Keterangan Gambar :

1. Tombol pengatur temperatur

2. Tombol pengatur temperatur

3. Stirrer / pengaduk

4. Beaker glass

3. Proses pemurnian minyak goreng bekas (Mardina, dkk., 2012)

Sampel minyak goreng bekas $150 \mathrm{~mL}$ dimasukkan ke dalam beaker glass kemudian ditambahkan serbuk biji alpukat ke dalam minyak dengan massa sebesar 2 gram. Selanjutnya dilakukan pengadukan selama 2 jam. Campuran minyak dan serbuk biji alpukat dipisahkan dengan cara filtrasi dan filtrat diambil untuk dianalisis asam lemak bebas dan bilangan peroksida minyak goreng bekas.

4. Penentuan Kadar Asam Lemak Bebas (FFA) (Ketaren, 2008)

Minyak sebanyak 5 gram ditimbang dalam erlenmeyer dan 
ditambahkan $50 \mathrm{~mL}$ etanol $96 \%$. Selanjutnya dipanaskan hingga mendidih selama 10 menit dan dikocok dengan kuat untuk melarutkan asam lemak bebas. Setelah dingin kemudian dititrasi dengan 0,1 N larutan $\mathrm{KOH}$ standar dengan menambahkan indikator phenolptalin hingga terbentuk warna merah muda yang bertahan tidak kurang dari 10 detik. Bilangan asam dinyatakan sebagai jumlah miligram $\mathrm{KOH}$ yang diperlukan untuk menetralkan asam lemak bebas yang terdapat dalam 1 gram minyak. Penentuan kadar asam lemak bebas atau Free Fatty Acids (FFA) pada minyak dihitung dengan menggunakan persamaan sebagai berikut:

Bilangan Asam

$$
\begin{gathered}
=\frac{\text { BM KOH }}{\text { BM Asam lemak bebas } / 10} \times \text { FFA } \\
\text { Bilangan asam }=\underset{\text { Faktor konversi } \mathrm{x}}{\% \text { FFA }}
\end{gathered}
$$

Faktor konversi untuk Oleat $=1,99$

Faktor konversi untuk Linoleat $=2,01$

Faktor konversi untuk Palmitat $=2,19$

Faktor konversi untuk Laurat $=2,80$

5. Penentuan Kadar Bilangan Peroksida (Sudarmadji, dkk., 2007)

Minyak sebanyak 5 gram ditimbang dan dimasukkan ke dalam erlenmeyer, selanjutnya ditambahkan $30 \mathrm{~mL}$ campuran pelarut yang terdiri dari $60 \%$ asam asetat glasial dan $40 \%$ kloroform. Setelah minyak larut kemudian ditambahkan 0,5 $\mathrm{mL}$ larutan $\mathrm{KI}$ jenuh sambil dikocok. Setelah 1 menit sejak penambahan larutan
KI jenuh ditambahkan $30 \mathrm{~mL}$ aquades, sehingga akan terjadi pelepasan iod $\left(\mathrm{I}_{2}\right)$. Iod yang bebas dititrasi dengan larutan $\mathrm{Na}_{2} \mathrm{~S}_{2} \mathrm{O}_{3}$ yang sudah distandarisasi $0,01 \mathrm{~N}$ hingga larutan berwarna kuning. Ditambahkan $0,5 \mathrm{~mL}$ indikator amilum $1 \%$ dan titrasi dilanjutkan hingga warna biru tepat hilang. Dihitung bilangan peroksida yang dinyatakan dalam mili-equivalen dari peroksida dalam setiap 1.000 g sampel.

Bilangan peroksida $=$

$$
\text { (S-B) x N x } 1000
$$

(Meq peroksida/Kg fat) berat sampel (g)

$S=$ titrasi sampel;

$\mathrm{B}=$ titrasi blanko,

$\mathrm{N}=$ Normalitas $\mathrm{Na}_{2} \mathrm{~S}_{2} \mathrm{O}_{3}$

6. Penyediaan Minyak Goreng Bekas

Minyak goreng bekas yang telah digunakan tiga kali penggorengan dalam jangka waktu tertentu.

\section{HASIL DAN PEMBAHASAN}

1. Preparasi dan Aktivasi Serbuk Biji Alpukat

Penelitian ini diawali dengan preparasi serbuk biji alpukat sebagai adsorben untuk menurunkan bilangan peroksida dan asam lemak bebas minyak goreng bekas. Bahan baku untuk preparasi adsorben dalam penelitian ini adalah limbah biji alpukat. Sebelum digunakan, biji alpukat dijemur dan dipotong di bawah sinar matahari selama 3 hari dengan tujuan untuk mengurangi kandungan air. Biji alpukat kemudian dihaluskan terlebih 
dahulu, dan diayak menggunakan ayakan 100 mesh.

Serbuk biji alpukat yang digunakan adalah yang lolos ayakan 100 mesh, seperti terlihat pada Gambar 2. Proses pengayakan dilakukan dengan tujuan untuk memperoleh ukuran partikel serbuk yang seragam sehingga dapat teraktivasi semua dan diketahui daya adsorptivitas pada proses adsorpsi antara adsorben dan adsorbat dengan ukuran partikel mesh yang telah ditentukan.

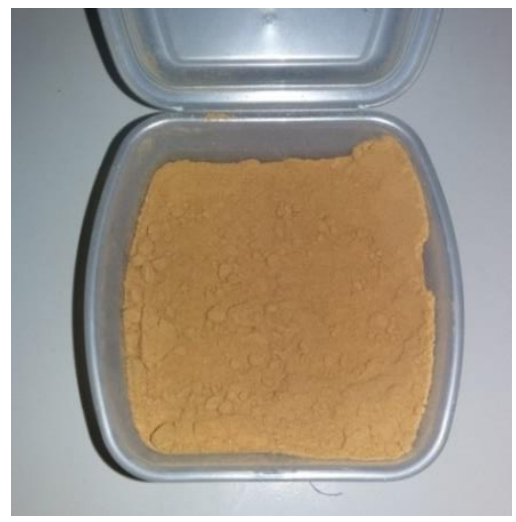

Gambar 2. Serbuk biji alpukat sebelum kalsinasi

Selanjutnya proses aktivasi dilakukan dengan tujuan untuk memperbesar pori sehingga serbuk mengalami perubahan fisik maupun kimia di mana luas permukaan bertambah besar sehingga berpengaruh terhadap daya adsorptivitas. Pada proses aktivasi, serbuk biji alpukat direndam dengan variasi zat aktivator yang berbeda yaitu larutan asam klorida $(\mathrm{HCl})$, asam sitrat $\left(\mathrm{C}_{6} \mathrm{H}_{8} \mathrm{O}_{7}\right)$, natrium klorida $(\mathrm{NaCl})$ dan natrium hidrogen fosfat $\left(\mathrm{Na}_{2} \mathrm{HPO}_{4}\right)$. Masing-masing larutan dan adsorben dilakukan pengadukan selama 2 jam. Tujuan dari perlakuan variasi zat aktivator ini untuk mengetahui hubungan antara pengaruh daya adsorbsi dari adsorben serbuk biji alpukat dengan menggunakan variasi zat aktivator terhadap kadar asam lemak bebas dan bilangan peroksida minyak goreng bekas.

Serbuk biji alpukat yang telah diaduk dengan variasi zat aktivator kemudian direndam selama 24 jam dan disaring dengan kertas saring. Selanjutnya serbuk dicuci dengan aquades guna menghilangkan zat-zat pengotor serbuk biji alpukat selama perendaman. Gumpalan serbuk biji alpukat yang diperoleh kemudian dikeringkan dalam oven pada suhu $60{ }^{\circ} \mathrm{C}$ selama 24 jam guna mengurangi kandungan air dalam serbuk biji alpukat, seperti terlihat pada Gambar 3.

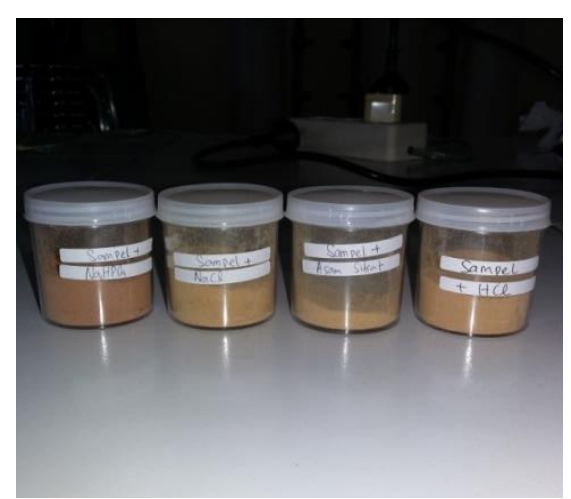

Gambar 3. Serbuk biji alpukat sesudah kalsinasi

2. Asam Lemak Bebas pada Variasi Zat Aktivator terhadap Adsorben Serbuk Biji Alpukat

Salah satu parameter penentu mutu minyak goreng adalah kadar asam lemak bebas yang terbentuk karena terjadinya reaksi hidrolisis 
minyak atau lemak. Reaksi ini dapat menyebabkan terjadinya kerusakan minyak karena adanya sejumlah air dalam minyak yang dipercepat dengan adanya faktorfaktor panas, air, keasaman dan enzim. Semakin lama reaksi hidrolisis yang berlangsung, maka semakin besar kadar asam lemak bebas yang terbentuk.

Tabel 1. Asam lemak bebas dengan berbagai variasi zat aktivator

\begin{tabular}{cc}
\hline Minyak & $\begin{array}{c}\text { Asam Lemak } \\
\text { Bebas (\%) }\end{array}$ \\
\hline $\begin{array}{c}\text { Minyak } \\
\text { Goreng Baru }\end{array}$ & 0,15 \\
\hline $\begin{array}{c}\text { Minyak } \\
\text { Goreng Bekas }\end{array}$ & 0,46 \\
\hline $\begin{array}{c}\text { Minyak }+ \\
\text { Aktivasi larutan } \\
\text { HCl }\end{array}$ & 0,26 \\
\hline $\begin{array}{c}\text { Minyak }+ \\
\text { Aktivasi larutan } \\
\mathrm{C}_{6} \mathrm{H}_{8} \mathrm{O}_{12}\end{array}$ & 0,36 \\
\hline $\begin{array}{c}\text { Minyak }+ \\
\text { Aktivasi larutan } \\
\text { NaCl }\end{array}$ & 0,31 \\
\hline $\begin{array}{c}\text { Minyak }+ \\
\text { Aktivasi larutan } \\
\mathrm{Na}_{2} \mathrm{HPO}_{4}\end{array}$ & 0,41 \\
\hline
\end{tabular}

Berdasarkan data pada Tabel 1, hasil yang diperoleh menunjukkan bahwa asam lemak bebas minyak goreng bekas tanpa ditambahkan serbuk biji alpukat (kontrol) sebesar 0,46\%. Tingginya asam lemak bebas minyak goreng bekas tersebut dapat disebabkan oleh tingginya tingkat kerusakan minyak karena adanya proses oksidasi dan hidrolisis (Nurbasnawati, 2015). Proses pemanasan pada suhu tinggi dan kontak minyak dengan udara dapat mempercepat proses oksidasi Sementara itu, proses hidrolisis terjadi akibat adanya sejumlah air dalam minyak dengan pemanasan yang berulang-ulang pada suhu tinggi dapat menyebabkan ikatan ester menjadi putus dan akhirnya terbentuk asam lemak bebas (Nasir, dkk., 2014).

Namun, setelah diberi perlakuan menggunakan serbuk biji alpukat yang diaktivasi dengan larutan $\mathrm{HCl} 1 \mathrm{M}$ dapat menurunkan kadar asam lemak bebas $(0,26 \%)$ minyak goreng bekas terbesar yakni $43,48 \%$. Kadar asam lemak bebas yang diperoleh masih memenuhi syarat dari Standar Nasional Indonesia (SNI) bilangan asam minyak goreng yaitu kurang dari 0,3\% (Dahlan, dkk., 2013). Asam lemak bebas minyak goreng bekas pada penambahan zat aktivator lain seperti larutan $\mathrm{C}_{6} \mathrm{H}_{8} \mathrm{O}_{7}, \quad \mathrm{NaCl}$ dan $\mathrm{Na}_{2} \mathrm{HPO}_{4}$ masing-masing menurun sebesar 0,36; 0,31 dan 0,41\% dibandingkan minyak goreng bekas tanpa perlakuan (kontrol). Oleh karena itu, hasil adsorpsi yang optimal pada penelitian ini diperoleh dari penambahan zat aktivator larutan $\mathrm{HCl} 1 \mathrm{M}$ menggunakan adsorben serbuk biji alpukat, karena dapat menurunkan asam lemak bebas minyak goreng bekas yang terbesar.

Asam lemak bebas minyak goreng bekas menurun setelah diadsorpsi dengan menggunakan serbuk biji alpukat pada berbagai variasi zat aktivator. Penurunan asam lemak bebas tersebut terjadi akibat penambahan serbuk biji alpukat yang dapat menyerap molekul asam lemak bebas. Hal ini terjadi karena serbuk biji alpukat 
mengandung selulosa yang banyak terdapat gugus hidroksil $(-\mathrm{OH})$ yang bersifat elektronegatif (basa) dan polar, sehingga dapat berinteraksi dengan gugus asam karboksilat (-COOH) dari asam lemak bebas yang bersifat elektropositif (asam) dan polar (Rahayu, dkk., 2014).

Penurunan asam lemak bebas dibandingkan dengan penelitian sebelumnya, yaitu Suryani (2009) menggunakan arang aktif tongkol jagung yang diaktivasi larutan $\mathrm{NaOH}$ 0,5 $\mathrm{N}$ mampu menurunkan asam lemak bebas minyak goreng bekas sebesar 18,40\%. Selain itu, penelitian Aisyah, dkk (2010) yang menggunakan karbon aktif polong buah kelor dengan aktivasi menggunakan larutan $\mathrm{NaCl}$ dapat menurunkan kadar asam lemak bebas minyak goreng bekas dengan penurunan terbesar pada proses netralisasi yaitu dari $0,35 \%$ menjadi $0,16 \%$.

\section{Bilangan Peroksida pada} Variasi Zat Aktivator terhadap Adsorben Serbuk Biji Alpukat Bilangan peroksida merupakan salah satu parameter penentu tingkat perubahan (kerusakan) pada minyak akibat terjadinya reaksi oksidasi pada proses pemanasan (Wiyaningsih, 2010). Minyak goreng yang digunakan berulang kali dan mengalami pemanasan pada suhu tinggi dapat menyebabkan terjadinya perubahan kimia dalam minyak sehingga terbentuk bilangan peroksida. Perubahan (kerusakan) dalam minyak goreng dapat dilihat dari tingginya bilangan peroksida dalam minyak goreng, Semakin tinggi bilangan peroksida pada minyak goreng maka semakin tinggi tingkat kerusakan minyak goreng tersebut. Kerusakan minyak goreng dapat disebabkan oleh dua faktor utama yaitu reaksi oksidasi dan hidrolisis yang menyebabkan terjadinya perubahan warna, rasa dan bau pada minyak goreng yang disebut dengan ketengikan. Proses oksidasi dapat berlangsung apabila terjadi kontak antara sejumlah oksigen dengan minyak atau lemak. Semakin sering minyak digunakan berulang kali maka semakin tinggi bilangan peroksida minyak goreng. Hal ini terlihat dengan adanya peningkatan bilangan peroksida setelah dilakukan penggorengan secara berulang. Proses penggorengan berulang kali dapat menyebabkan meningkatnya suhu minyak goreng.

Penentuan bilangan peroksida pada penelitian ini dilakukan dengan metode iodometri (Sudarmadji, dkk., 2007). Sampel minyak goreng bekas dilarutkan dalam campuran asam asetat glasial dan kloroform dengan perbandingan 3:2 yang berfungsi sebagai pelarut organik yang larut dalam minyak goreng dan mengandung kalium iodida (KI) sehingga terjadi pelepasan Iod $\left(\mathrm{I}_{2}\right)$. Iod yang bebas dititrasi dengan natrium thiosulfat menggunakan indikator amilum sampai warna biru hilang. Larutan amilum 1\% berfungsi sebagai indikator untuk menentukan titik akhir titrasi. Larutan amilum harus disimpan pada tempat yang dingin karena larutan ini mudah rusak. Natrium thiosulfat harus distandarisasi 
terlebih dahulu agar konsentrasi larutan selalu stabil sehingga tidak terjadi kesalahan pada penentuan bilangan peroksida.

Tabel 2. Bilangan peroksida dengan berbagai variasi zat aktivator

\begin{tabular}{|c|c|}
\hline Minyak & $\begin{array}{l}\text { Peroksida } \\
\text { (Meq/Kg ) }\end{array}$ \\
\hline $\begin{array}{c}\text { Minyak } \\
\text { Goreng Baru } \\
\end{array}$ & 1,0 \\
\hline $\begin{array}{c}\text { Minyak } \\
\text { Goreng Bekas }\end{array}$ & 3,6 \\
\hline $\begin{array}{c}\text { Minyak + } \\
\text { Aktivasi larutan } \\
\mathrm{HCl}\end{array}$ & 3,0 \\
\hline $\begin{array}{c}\text { Minyak + } \\
\text { Aktivasi larutan } \\
\mathrm{C}_{6} \mathrm{H}_{8} \mathrm{O}_{12} \\
\end{array}$ & 1,8 \\
\hline $\begin{array}{c}\text { Minyak + } \\
\text { Aktivasi larutan } \\
\mathrm{NaCl} \\
\end{array}$ & 3,2 \\
\hline $\begin{array}{c}\text { Minyak + } \\
\text { Aktivasi larutan } \\
\mathrm{Na}_{2} \mathrm{HPO}_{4} \\
\end{array}$ & 2,6 \\
\hline
\end{tabular}

Pada penelitian ini dilakukan perhitungan bilangan peroksida minyak goreng bekas baik pada kelompok murni, kontrol maupun kelompok perlakuan. Penambahan adsorben serbuk biji alpukat menggunakan berbagai variasi zat aktivator dalam minyak goreng bekas dapat menyebabkan terjadinya penurunan bilangan peroksida. Kontrol dari berbagai variasi zat aktivator seperti larutan $\mathrm{HCl}$, $\mathrm{C}_{6} \mathrm{H}_{8} \mathrm{O}_{12}, \quad \mathrm{NaCl}$ dan $\mathrm{Na}_{2} \mathrm{HPO}_{4}$ menggunakan serbuk biji alpukat sebagai adsorben dari minyak goreng bekas berturut-turut adalah 3,$0 ; 1,8 ; 3,2$ dan $2,6 \mathrm{Meq} / \mathrm{Kg}$ (Tabel 2). Sehingga penggunaan larutan $\mathrm{C}_{6} \mathrm{H}_{8} \mathrm{O}_{7}$ sebagai zat aktivator serbuk biji alpukat memberikan penurunan bilangan peroksida terbaik pada minyak goreng bekas sebesar $50 \%$ dan memenuhi syarat batas maksimal SNI yaitu maksimal $2 \mathrm{Meq} / \mathrm{Kg}$ untuk bilangan peroksida minyak goreng (Dahlan, dkk., 2013).

Penurunan

bilangan peroksida tersebut disebabkan oleh serbuk biji alpukat dapat berinteraksi dengan minyak goreng bekas secara optimal dalam menyerap senyawa peroksida. Hal ini dapat dilihat dari perubahan fisik pada minyak goreng bekas setelah diaktivasi dimana warna keruh berubah menjadi lebih jernih, aroma dan bau tengik yang tidak disukai menjadi berkurang akibat terserapnya zat-zat pengotor pada minyak goreng bekas. dengan penelitian sebelumnya mengenai penentuan bilangan peroksida dalam minyak goreng bekas dengan cara titrasi, dilakukan oleh Yustinah dan Harini (2011). Hasil penelitian menunjukkan bahwa bilangan peroksida pada minyak goreng bekas hasil adsorbsi terendah terdapat pada adsorben campuran bentonit, pasir kuarsa, dan karbon aktif dengan aktivator larutan $\mathrm{HCl}$ sebesar 1,2 Meq/Kg dan waktu aktivasi 24 jam. Namun pada penelitian Nasir, dkk (2014) hasil yang diperoleh menunjukkan bahwa bilangan peroksida minyak goreng bekas tanpa ditambahkan arang aktif kulit pisang (kontrol) sebesar 11,46 Meq/Kg, sedangkan bilangan peroksida setelah diberi perlakuan variasi konsentrasi larutan $\mathrm{NaOH}$ berkisar antara 6,88 
- 10,21 Meq/Kg atau terjadi penurunan sebesar 39,37\%. Penurunan kadar bilangan peroksida tersebut diperoleh setelah minyak goreng bekas diaktivasi menggunakan arang kulit pisang dengan aktivator larutan $\mathrm{NaOH}$ konsentrasi $1 \mathrm{~N}$.

\section{SIMPULAN DAN SARAN}

Dari penelitian yang telah dilakukan ini dapat disimpulkan bahwa jenis aktivator dari serbuk biji alpukat yang terbaik dalam penyerapan asam lemak bebas pada minyak goreng bekas adalah $\mathrm{HCl}$ dengan waktu aktivasi 24 jam menghasilkan \%FFA sebesar $0,26 \%$. Sedangkan untuk menurunkan bilangan peroksida yang terbaik adalah serbuk biji alpukat yang diaktivasi menggunakan aktivator $\mathrm{C}_{6} \mathrm{H}_{8} \mathrm{O}_{7}$ dengan waktu aktivasi 24 jam menghasilkan bilangan peroksida sebesar 1,8 Meq/Kg. Pemurnian minyak goreng secara adsorbsi menggunakan serbuk biji alpukat teraktivasi menjadikan minyak hasil regenerasi dapat dikonsumsi kembali karena menghasilkan bilangan asam dan bilangan peroksida yang memenuhi syarat batas maksimal SNI minyak goreng.

Saran untuk penelitian selanjutnya perlu dilakukan variasi konsentrasi aktivator dan waktu aktivasi pada proses pembuatan adsorben dari biji alpukat untuk mengetahui proses adsorbsi serbuk biji alpukat terhadap asam lemak bebas dan bilangan peroksida dalam minyak goreng bekas.

\section{DAFTAR PUSTAKA}

Aisyah, S., Yulianti, E \& Fasya, A.G. (2010). Penurunan Angka Peroksida dan Asam Lemak Bebas (FFA) pada Proses Bleaching Minyak Goreng Bekas oleh Karbon Aktif Polong Buah Kelor (Moringa Oliefera Lamk) dengan Aktivasi NaCl. Alchemy. Vol. 1. No. 2.

Alsuhendra, Zulhipri, Ridawati \& Lisanti, E. (2007). Ekstraksi dan Karakteristik Senyawa Fenolik dari Biji Alpukat (Persea Americana Mill.). Proseding Seminar Nasional PATPI. Bandung (ID).

Dahlan, M.H., Siregar, H.P \& Yusra, M. (2013). Penggunaan Karbon Aktif dari Biji Kelor dapat Memurnikan Minyak Jelantah. Jurnal Teknik Kimia. Vol. 19. No. 3.

Kalapathy, U \& Proctor, A. (2000). A New Method for Free Fatty Acid Reduction in Frying Oil Using Silicate Films Produced from Rice Hull Ash. Journal of the American Oil Chemists' Society. Vol. 77 No. 6.

Fitriani, Kurniati, $\mathrm{T}$ \& Hambali. (2017). Penyerapan Ion Logam $\mathrm{Pb}$ (II) dari Larutan Menggunakan Serbuk Daun Puring (Codiaeum Variegatum). Jurnal Pendidikan Matematika dan IPA. Vol. 8. No. 1.

Ketaren, S. (2008). Pengantar Teknologi Minyak dan Lemak Pangan. Jakarta: Universitas Indonesia Press. 
Mangallo, B., Susilowati \& Wati, S.I. (2014). Efektivitas Arang Aktif Kulit Salak pada Pemurnian Minyak Goreng Bekas. Chem. Prog. Vol. 7. No. 2.

Mardina, P., Faradina, E \& Setiawati, N. (2012). Penurunan Bilangan asam pada Minyak Jelantah. Jurnal Kimia. Vol. 6. No. 2.

Nasir, N.S.W., Nurhaeni \& Musafira. (2014). Pemanfaatan Arang Aktif Kulit Pisang Kepok (Musa Normalis) Sebagai Adsorben Untuk Menurunkan Angka Peroksida dan Asam Lemak Bebas Minyak Goreng Bekas. Online Jurnal of Natural Science. Vol. 3. No. 1.

Nurbasnawati, H. (2015). Penetapan Kadar Asam Lemak Bebas dan Bilangan Peroksida pada Minyak Goreng yang digunakan Pedagang Gorengan di Jalan A.W Sjahranie Samarinda. Jurnal Ilmiah Manuntung. Vol. 1 No. 1.

Rahayu, L.H., Purnavita, S \& Sriyana, H.Y. (2014). Potensi Sabut dan Tempurung Kelapa sebagai Adsorben untuk Meregenerasi Minyak Jelantah. Akademi Kimia Industri "Santo Paulus" Semarang. Vol. 10. No. 1.

Rahayu, L.H \& Purnavita, S. (2014). Pengaruh Suhu dan Waktu Adsorpsi terhadap Sifat KimiaFisika Minyak Goreng Bekas Hasil Pemurnian menggunakan Adsorben Ampas Pati Aren dan Bentonit. Momentum. Vol. 10. No. 2.
Ramdja, A.F., Febriana, L \& Krisdianto, D. (2010). Pemurnian Minyak Jelantah Menggunakan Ampas Tebu sebagai Adsorben. Jurnal Teknik Kimia. Vol. 17. No. 1 .

Sabahannur, St \& Nirwana. (2017). Kajian Pengaruh Berat Biji Kakao Perkotak dan Waktu Pengadukan terhadap Keberhasilan Proses Fermentasi. Jurnal Pendidikan Matematika dan IPA. Vol. 8 No. 2.

Sudarmadji, S., Bambang, H \& Suhardi. (2007). Analisis Bahan Makanan dan Pertanian. Edisi Kedua. Yogyakarta: Penerbit Liberty.

Suirta, I.W. (2009). Preparasi Biodiesel dari Minyak Jelantah Kelapa Sawit. Jurnal Kimia. Vol. 3. No. 1.

Suryani, A.M., (2009). Pemanfaatan Tongkol Jagung untuk Pembuatan Arang Aktif sebagai Adsorben Pemurnian Minyak Goreng Bekas. Skripsi Departemen Kimia Institut Pertanian Bogor, Bogor.

Wijayanti. H., Nora, H \& Amelia, R. (2012). Pemanfaatan Arang Aktif dari Serbuk Gergaji Kayu Ulin untuk Meningkatkan Kualitas Minyak Goreng Bekas. Konversi. Vol. 1 No.1. 
Wiyaningsih, F. (2010). Pengaruh Variasi Suhu Pemanasan Karbon Aktif Polong Buah Kelor (Moringa Oleifera Lamk) terhadap Perubahan Angka Peroksida dan Asam Lemak Bebas (FFA) pada Proses Bleaching Minyak Goreng Bekas. Skripsi Universitas Islam Negeri Maulana Malik Ibrahim, Malang.
Yustinah \& Hartini. (2011). Adsorpsi Minyak Goreng Bekas Menggunakan Arang Aktif dari Sabut Kelapa. Prosiding Seminar Nasional Teknik Kimia “Kejuangan”. Jurusan Teknik Kimia, Fakultas Teknik, Universitas Muhammadiyah Jakarta. Jakarta. 